\title{
S100A1 Gene
}

National Cancer Institute

\section{Source}

National Cancer Institute. S100A1 Gene. NCI Thesaurus. Code C99608.

This gene plays a role in zinc and calcium binding. 